The oscillation envelope, shown in Fig. $2 A$, is not continuous so that variations of $M_{z}$ should occur only during the intermittent pulses, leading to shock excitation of the pick-up coils. This was found to be advantageous because the response time of the system is too long to record completely the variations of $M_{z}$. In Fig. $2 B$ there are shock excitations coincident with the first three oscillation pulses. This coincidence was checked in a special experiment. The rising baseline is due to the residual pick-up from the swept field. This evidence, in support of the nutating character of $M$, is further substantiated by the fact that no effect was observed when the inverting microwave power was reduced below the level necessary to sustain maser oscillations so that only the residual pick-up was observed.

This experiment establishes the existence of variations of $M_{z}$ and therefore of the nutations of $M$ during emission. Further measurements of $M_{z}$ will, very likely, provide useful information on the mode of operation of maser oscillators. The technique described could be improved, to give detailed measurements of $M_{z}$, either by using critical damping in the pick-up coils, or by modifying the system to respond to the nutations of $M$ as modulations of a highfrequency carrier wave fed to the coils.

We are indebted to Prof. J. F. Allen for placing low-temperature facilities at our disposal and to the Royal Naval Scientific Service for the interest shown in this work.

\section{M. FiRTH}

D. BIJL

School of Natural Philosophy,

University of St. Andrews.

' Feher, G., Gordon, J. P., Buehler, E., Gere, E. A., and Thormund, C. D., Phys. Rev., 109, 221 (1958).

${ }^{2}$ Chester, P. F., Wagner, P. E., and Castle, jun., J. G., Phys. Rev.,110, $281(1958)$.

${ }^{3}$ Kemp, J. C., J. App. Phys., 30, 1451 (1959).

+ Wang, s., and Singer, J. R., J. App. Phys., 32, 1371 (1961).

- Yariv, A., J. App. Phys, 31, 740 (1960).

- Stevens, K. W. H., and Josephson, jun., B., Proc. Phys. Soc., 74, $561(1959)$

${ }^{7}$ Campbell, C. K., and Bijl, D. (to be published).

sirth, I. M. (to be published).

\section{GEOLOGY}

\section{Occurrence of Magnesite-Dolomite Sediments in South Australia}

Is November 1960 samples of precipitating sediment were taken from a lagoon of saline water near Salt Creek in the south-east province of South Australia. These were found to consist of magnesite and dolomite in about equal proportions. The salinity of the water was $3 \cdot 2$ per cent, and analysis showed that calcium constituted a much smaller proportion of the total salts than in normal sea-water. The proportion of magnesium was also lower. The $p \mathrm{H}$ was about 10 .

Samples were taken from the bed of the lagoon after it had become dry during the summer. At the surface the proportions of magnesite and dolomite were approximately equal. At a depth of 6 in. the approximate composition was magnesite 20 per cent, dolomite 80 per cent. At 10 in., magnesite was no longer detectable and the sediment consisted entirely of dolomite. This persisted to a depth of 20 in., where it graded sharply into black sulphidebearing sands.
X-ray examination of the magnesite showed that the lattice was expanded when compared with normal magnesite. The lattice constants were estimated as $a_{0}=4 \cdot 66$ and $c_{0}=15 \cdot 23$. This may be compared with the magnesium carbonate described by D. L. Graf, A. J. Eardley and N. F. Shimp ${ }^{1}$ from Lake Bonneville, U.S.A., which has a significantly expanded unit cell with lattice constants $a_{0}=4 \cdot 669$ and $c_{0}=15 \cdot 21$.

Last year we ${ }^{2}$ recorded the occurrence of hydromagnesite-aragonite sediments in a similarly situated lagoon which is about 8 miles south of the lagoon in which the magnesite-dolomite is forming. This new discovery may throw more light on the origin of the magnesite-dolomite sediments of Proterozoic age in South Australia.

We believe this to be the first recorded observation of naturally precipitating magnesite-dolomite sediment.

This work is supported by grants from the American Petroleum Institute.

A. R. Alderman

C. C. VON DER BORCH

School of Geology,

University, Adelaide.

${ }^{1}$ Graf, D. L., Eardley, A. J., and Shimp, N. F., J. Geol., 69, 219 (1961). Alderman, A. R., and von der Borch, C. C., Nature, 188, 931 (1960).

\section{CRYSTALLOGRAPHY}

\section{X-ray Data for the Chrome-Urania System, $\mathrm{Cr}_{2} \mathrm{O}_{3} \cdot 2 \mathrm{UO}_{3}$}

A NEW binary compound in the chrome-urania system has been briefly described by Borchardt'. This compound has been prepared by mechanically mixing 78 weight per cent uranium oxide $\left(\mathrm{UO}_{2}\right)$ and 22 weight per cent chromium oxide $\left(\mathrm{Cr}_{2} \mathrm{O}_{3}\right)$, pressing the mixture into pellets and firing to $1,250^{\circ} \mathrm{C}$. in platinum dishes. The samples were reground and refired and then examined by chemical, optical, and X-ray techniques. A trace of free chrome was observed optically in mixtures where the chemical analysis indicated excess chromium over a $\mathrm{Cr}$ : $\mathrm{U}$ atom ratio of 1 . The X-ray powder patterns indicated only one phase.

The preparations were black, with grain sizes less than $50 \mu$. Two small crystals which were recovered from the preparations showed external morphology with $6 / m$ symmetry. Single-crystal precession photographs, however, showed the erystals to be truly orthorhombic with three-fold interpenetrant twinning producing the pseudo-hexagonal habit. Fig. I shows the true orthorhombic lattice and its relation to the twin in the $0 k l$ zone. Of particular interest is the superposition of the 002 and 041 reflexions. Table 1 lists the $\mathrm{X}$-ray powder pattern along with the indexing based on the cell determined from the single. crystal patterns. Table 2 lists the cell data and optical properties of the compound.

The presence of the pseudo-hexagonal twinning suggested the possibility of a high-temperature inversion to a truly hexagonal phase. Using a hot-stage furnace (Materials Research Corporation), samples were examined in air up to $1,400^{\circ} \mathrm{C}$., but no evidence for the expected phase change was found. However, samples left at $1,250^{\circ} \mathrm{C}$. for several days developed clusters of multiple and single crystals of the compound on the surface of the sample. The crystals were yellow-brown tabular crystals with a rectangular outline. Most of the crystals were twinned, producing 